\title{
HAEMATOLOGY AND ONCOLOGY
}

\section{3}

Giastro-oesophageal rellux (GIIR) and Al:Tl in babies: Role of Beta Endorphins? M.A. SERRE, P MONIN, F JEILLIT, B. DOLSSET, M VILNILIIIT Services de medecine infantile, Iaboraloire de Biochimie Clltl de NANCY BLABOIS , 54511 VANDOLUVRL GRANCl: - Malernite regionale NANCl

GER is frequently observed during the first months of life and is now cousidered as a significant risk facior for ALTE or SIDS. To cviluale the polential role of Beta endorphins in the pithogenesis of Altit in the presence of Gik, 2 groups of babies are studied. fifteen babies admilled for Altl and presenting a Gik (Cir 1) are compared (o) is siblings of sil)s patients also having a GER diagnosed at 1 month of age when investigated patients also having a GER diagnosed at $\mathrm{Gr}_{2}$. GER was evaluated by oesophageal pll recordings. plasma Beta endorphins levels were measured with radioimmunologic method (Allegro Beta endorphins Reagents - Nichols Institute Diagnostics USA) following AITE in Gr 1 and on the day of evaluation at 1 montl of age in Gr 2 . The 2 groups were comparable for birth weight a sestitionnal age and sex ratio. The severity of GER assessed by oesophageal pil was also similar in the 2 groups: acidity index ( $\%$ of the recording period with pll below 4) was respectively of $10,6 \%+3,5 \%$ in $\mathrm{gr} 1$ and $13,9 \%+5,6 \%$ in $\mathrm{gr} 2$ The number of reflux per hour was $11+6$ and $16+5$. Plasma $B$ endorphin levels was $84.5+80 \mathrm{pg} / \mathrm{ml}$ in gr $1(15-312$, median $47 \mathrm{pg} / \mathrm{ml})$ and $25.9+31$ $\mathrm{pg} / \mathrm{ml}$ in $\mathrm{gr} 2(5-91 \mathrm{pg} / \mathrm{ml}$, median $14 \mathrm{pg} / \mathrm{ml}) \mathrm{p}<0,01$. In groun 1 , thabics had levels above $125 \mathrm{pg} / \mathrm{ml}$ (normal nean plasma level :29 pg/ml).

These data suggest

1) GER can be associated to an increased production of Bela endorphins probably in response to the oesophageal insult induced by acidity.

2) the depressive effect of $B$ endorphins on respiration might increase the vuluerability of babies with GIR 10 AITIE.

\section{4}

MYY APNEA REFLEX INDUCE SUDDEN INFANT DEATHI

Hanne Storm, Lauritz Stoltenberg, Tom Sundar, Ola D Saugstad, Torleiv O Rognum and Karl L Reichelt. Departement of Pediatric Research and Institute of Forensic Medicine, Rikshospitalet, Oslo, Norway.

Beta-endorphin may induce resplratory depression and bradycardia. Elevated hypoxanthine (HX) level in corpus vitreum humor (CVH) indicates hypoxia before death. We measured beta-endorphin immunoreactivity (BEI) in CSF and $H X$ in CVI in SIDS victims $(n=27)$ and in control infants $(n=12)$. In a pilot study we measured BEI in CSF in piglets where the larynx reflex was induced by ammonium gas $(n=4)$. BEI in CSF was also measured after brain hypoxia in piglets $(n=6)$.

in CSF was also measured after brain hypoxid in piglets subpopulations: one half with undetectable level $<4.3 \mathrm{fmol} / \mathrm{ml} \mathrm{CSF}$, and the other half with high level $247 \mathrm{fmol} / \mathrm{ml}$ CSF (range 160-400). Ail the SIDS victims had elevated levels of $\mathrm{HX}$ in $\mathrm{CVH} 209 \mathrm{mikromol} / \mathrm{l}$ (range 53-419) compared with the controls that died a sudden death (accidental, cardial or strangled). which had $54 \mathrm{mikromol} / 1$ (range 0 188). In the subpopulation of SIDS victims with elevated bEI in CSF, we found a positive correlation between BEI in CSF and IIX levels in $C V H \quad r=0.92 \quad(p<0.001)$. In the control infants no correlation between $B E I$ in CSF and lix in CVH was found. In plglets where the larynx reflex was excited, we found increased levels of BEI in CSF which correlated with the duration of the apneas $x=0.84 \quad(p=0.16)$. In the control piglets undetectable levels of BEI in CSF was found.

Conclusion: In SIDS victims with elevated levels of BEI in CSF, the BEI correlated with HX in CVH. The larynx reflex induced apneas, induced BEI increase in CSF in piglets.

\section{6}

IHU-ERYTHROPOIETIN (IIH-EPO) IN THE PREVENTION OF ANEMIA OF PREMATURITY: EFFECTS ON ENDOGENOUS ERYTHROPOIESIS. Heike Rabe - Thomos Brune. Erik Michel, Susanne Lindner, Hartmut Ebbecke, Gerhard Jorch. Children's University Hospital, Münster, "University Laboratories. Regensburg. FRG
Introduction; rH-EPO has been studied as a new treatment regime for the anemia Introduction; iH-EPO has been studied as a new treatment regime for the anem
of prematurity in two multicentre studies in order to avoid red cell transfusion of prematurity in two multicentre studies in order to avoid red cell transfusion
with its potential hazards. Methods; We randomly assigned 29 premature infants to 2 treatment schedules with rH-EPO or none. Infants in treatment group 1 i $n=8$, mean BW $1436+1.357 \mathrm{~g}$, mean $\mathrm{GA} 31 \mathrm{w}$ ) received $70 \mathrm{IU} \mathrm{rH}-\mathrm{EPO} / \mathrm{kgBW} / \mathrm{w}$ upto day 25 of life by subcutaneous injection into thigh, those in treatment group 2 $(n=6$. mean BW $1284+1-148 \mathrm{~g}$. mean GA $31 \mathrm{w}) 750 \mathrm{UI} / \mathrm{kgBW} / \mathrm{w}$ upto day 42 of lifo, those in the control group in $=15$, mean BW $1327+1.316 \mathrm{~g}$, mean GA $30 \mathrm{w}$ received no treatment. All infants received supplemental iron orally from day 14 o study pariod Mean number of packed red cell transfusions per potient during the IU groupl. Mean reticulocyte counts were at 70 group) and 0.17 units $(750$ (controls). Mean reticulocyte counts were at day 3 of life were $10.1+1.5 \%$ (controls). $8.8+1.4 .4 \%$ (75 IU group) and $8.2+1.6 .5 \%$ (750 IU group). In both the control and the 75 IU group mean reticulocytes count decreased during IU group to a highest value of $10.6+1-2.3 \%$ in week 3 and stayed at a high level of 7 to $8 \%$ until week 5 . Mean absolute normocyte count fell in a logarithmic manner but values wero higher in both treatment groups. The biggest difference was observed in week 4 with a mean of 180 normocytes in the 750 IU group. 75 EPO showed no sufficient effect for the treatment of anemia of prematurity. High dose rH-EPO prevents the need for transfusion in preterm infants, stimulates endogenous generation of normovolaemic hypochrome erythrocytes and does not stimulate other cell lines than the red cell line.

\section{5}

MEASURINO BODY FAT IN INFANCY: ANTHROPOMETRY VERSUS TOTAL BODY ELECTAICAL CONDUCTIVITY (TOBCC)

N.C. Do Bruin, C.A.M. Van Volthoven, T. Brugman, H.J. Degenhar, H.K.A. Visser Department of Pediatrics, Sophia Childrens Hospital and University Hospital, Erasmus University Rotterdam. The Netherlands.

TOBEC is a rapid, sale and convenient method for the measurement of body compositi. on. Cross-sectional measurement of body fat (BF) by TOBEC (BF-T) and by anthropome. try including skinfold thickness ' (BF.S) was performed in 423 normal, healthy caucasian infants, allowing comparison of these techniques with each other and with reference data on body $\mathrm{fat}^{2}$ (BF-A). Pesults in percentage BF $(\% \mathrm{BF})$

\begin{tabular}{ccccccc} 
AGE & \% BF-A & \multicolumn{3}{c}{ \% BF-T } & \multicolumn{2}{c}{ \% BF.S } \\
months & bovs & girls & bovs & oirls & boys & oirls \\
1 & 15.1 & 16.2 & 13.0 & 12.4 & 10.3 & 9.1 \\
2 & 19.9 & 21.1 & 18.5 & 18.1 & 14.6 & 13.8 \\
3 & 23.2 & 23.8 & 20.3 & 21.4 & 14.8 & 15.5 \\
4 & 24.7 & 25.2 & 24.0 & 24.4 & 17.0 & 17.1 \\
5 & 25.3 & 26.0 & 24.4 & 25.6 & 17.5 & 17.0 \\
6 & 25.4 & 26.4 & 24.6 & 27.1 & 16.7 & 19.1 \\
9 & 24.0 & 25.0 & 25.6 & 27.6 & 18.9 & 20.1 \\
12 & 22.5 & 23.7 & 23.8 & 25.4 & 19.7 & 23.5 \\
\hline
\end{tabular}

OF.T was corrolatod with OF.S. Exprossod in percontagos $1=0.550$ (1) $<0.00011$ oxpressed in orams $r=0.780$ ip $<0.0001)$. Biological plus oxporimental scattor texpros sod as CV) was much highor in the BF.S data. Conclusions: 11 BF.T in intancy wore slightly lower, but in close agreemont with rolerence data from Fomon ot al. 2) UF.S values were consistently lower than DF-T values. 3) The difference between BF-T and BF-S may represent non-subcutaneous BF. 'Dauncey of ol. Arch Dis Child $52: 223$ 227, 1977 Fomon ot el. Am J Clin Nutr 35:1169-75, 1982

\section{7}

HUTATIONAL ACTIVATION OF N-RAS-12 GENE IS ABSENT IN PEDIATRIC OSTEOSARCOMA. Federico Antillon, Marina GarciaDelgado, Luis Sierrasúmaga, Ignacio Villa-Elizaga. Departments of Pediatrics and Genetics. Pediatric taboratory. Universitary Clinic. School of Medicine. Universidad de Havarra. Pamplona, Spain.

Activation of $r a s$ oncogenes is found in human cancers, cverall it is observed in 158 of all neoplasms. OBJECTIVE: The purpose of this study was to assess the extent of involment of ras oncogenes in osteosarcoma. STUDY DESIGN Tumor samples from a series of 53 pediatric patients diagnosed of osteosarcoma and treated at our institution were evaluated. Parraffin-embedded tumor samples from diagnostic biopsies, from tissue of tumor en bloc resection after neoadjuvant chemotherapy, and samples from metastases were examined for point mutations at the N-ras-12 gene by means of polymerase chain reaction (PCR), slot-blotting, and radioactive labelled specific DNA probes. RESULTS: total of 133 archival samples were studied. No point mutations activating the $N-r a s-12$ gene were found. coliclusions: In order to exclude the potential role of the ras gene family in the development of ostesarcomas codon 61 of the N-ras gene and codons 12 and 61 of genes $\|-r a s$ and $\mathrm{K}$-ras must evaluated. These studies are been purformed. Archival tumor samples are adequate for PCk amplification. PCR greatly facilitates the study of oncogene activation in tumor samples.

INTRA VENTRICULAR STREPTOKINASE INCREASES CEREBROSPINAL
FLUID D DIMER IN PRETERM INFANTS WITH POSTHAEMORRHAGIC FLUID D DIMER IN

Andrew Whitclaw, Ulrich A bildgaard, Department of Pacdiatrics \& Hacmatology Rescarch Laboratory, Unitersity of Oslo. Aker l lospital, Oslo, Norw:1 Failure to lyse multiple small bloxd clots in the cercbrospinal fluid (CSF)

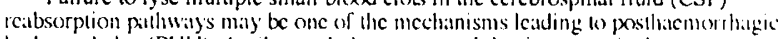
hydrocephalus (PHH). A pilot study lias sugegested that intrasicntricular

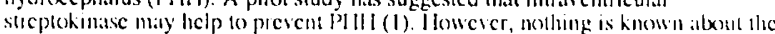

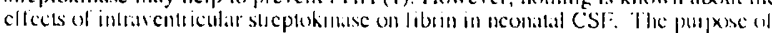
tlis study was k decomine whether intratentricular administratton of

siscplokimase produces an increase in fibrin degradation preducts in the CSF:

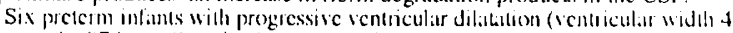

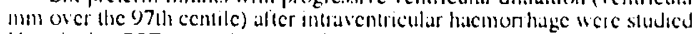
$\checkmark$ vatuicular CSF wass collected before and during intraticntricular tecatment with

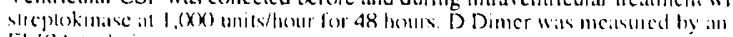

ELISA IColunique

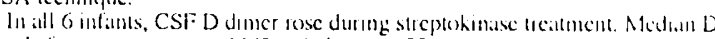

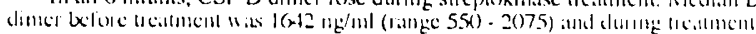

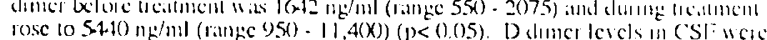

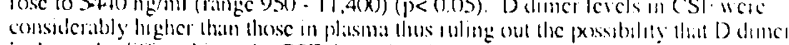

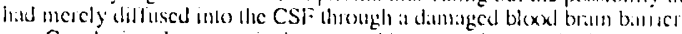

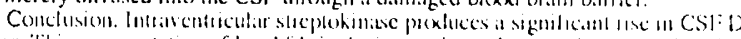

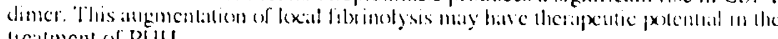
licitment of pllt

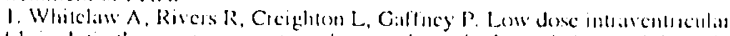

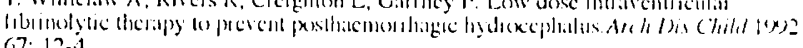

(17: $12-4$ 